\title{
Collapse of a historic oyster fishery: diagnosing causes and identifying paths toward increased resilience
}

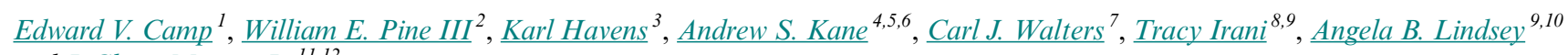 \\ and J. Glenn Morris, $\mathrm{Jr}^{11,12}$
}

\begin{abstract}
Diagnosing causal factors of change at the ecosystem level is challenging because multiple drivers often interact at various spatial and temporal scales. We employ an integrated natural and social science approach to assess potential mechanisms leading to the collapse of an estuarine social-ecological system, and recommend future paths to increased system resilience. Our case study is the collapse of the eastern oyster (Crassostrea virginica) fishery in Apalachicola Bay, Florida, USA, and the associated impacts on local resource dependent communities. The oyster fishery collapse is the most recent in a series of environmental stressors to this region, which have included hurricanes and tropical storms, drought, and the Deepwater Horizon oil spill. We found it likely that the oyster collapse was not related to contamination from the recent oil spill, but rather to factors affecting oyster recruitment and survival, which may have been mediated by both human, e.g., fishing-related habitat alteration, and environmental, e.g., increased natural mortality from predators and disease, factors. The relative impact of each of these factors is likely to increase in the future because of changing climate and increased demand for fishery, water, and petroleum resources. Successful restoration and persistence of a viable oyster fishery will depend on: (1) implementation of some minimal best management practices, e.g., extensive habitat restoration via shell addition, and some spatial closures to harvest, (2) improving environmental knowledge and promoting episodic learning through enhanced monitoring and experimental management, and (3) continued community engagement necessary to produce adaptable governance suitable to responding to future unexpected challenges.
\end{abstract}

Key Words: climate change; community resilience; drought; estuaries; oyster fishery

\section{INTRODUCTION}

Estuaries exist at the interface of ocean and fresh water and these productive and biologically diverse ecosystems provide critical services to coastal human communities throughout the world (Grabowski and Peterson 2007, Barbier et al. 2011). Among aquatic ecosystems, estuaries are particularly sensitive to change because relatively small alterations in salinity can affect rates of predation, disease, and physiology of the estuarine biota, which are adapted to intermediate levels of salinity (Visser et al. 2002, Buzan et al. 2009, Petes et al. 2012). Maintenance of estuary ecosystem services depends on the resilience of the socialecological system: how natural resources, their users, and the governance systems respond to (often unexpected) change (Berkes and Folke 1998, Olsson et al. 2004, Gunderson 2010). In a future of elevated biosphere temperature, associated changes in evapotranspiration or precipitation patterns will likely reduce water input to estuaries at the same time that sea level is rising, allowing greater incursion of salt water from the ocean (Graeff et al. 2013, Ingram 2013). These effects may be exacerbated in areas where droughts are common, when low riverine flow reduces nutrient and fresh water inputs into estuaries (Elsdon et al. 2009). These changes may particularly impact sessile biota such as the eastern oyster (Crassostrea virginica; hereafter "oyster"), which becomes more prone to disease (Petes et al. 2012), and impacts of marine predators (Oczkowski et al. 2011, Rindone and Eggleston 2011) under increased salinity conditions.
An area potentially sensitive to such climate-change-driven alterations is Apalachicola Bay, in the Gulf of Mexico in the southeastern USA. This estuary is fed by a large river system (the Apalachicola-Chattahoochee-Flint, or ACF basin) that spans the boundaries of three states, Georgia, Alabama, and Florida (Fig. 1). The river and its series of man-made dams and reservoirs provide flood protection; provide water supply to urban, residential, and agricultural users; and are the primary fresh water input to the Apalachicola estuary at the river's mouth. Apalachicola Bay supports an economically important oyster fishery known for its high quality product that historically has accounted for $90 \%$ of oysters sold in Florida and over $10 \%$ of oysters sold in the continental USA (USACE 1998). The Apalachicola River has a history of drought and flood, and the bay has a contemporaneous history of wax and wane of its oyster population (Wilber 1992, Livingston et al. 1997, Livingston 2015, Pine et al. 2015). Apalachicola Bay oysters and the oyster fishery have also experienced negative impacts from tropical storms that may alter habitat (Berrigan 1988), increased predator abundance and disease occurrence during drought (Menzel et al. 1966, Petes et al. 2012), and fluctuations in market demand. All of these factors can and have led to temporally variable oyster abundance and harvests (Pine et al. 2015).

The years 2004-2013 were a period of significant societal and ecological stress in the Apalachicola Bay region. This stress was

${ }^{1}$ Fisheries and Aquatic Sciences Program, School of Forest Resources and Conservation, University of Florida, ${ }^{2}$ Department of Wildlife Ecology and Conservation, University of Florida, ${ }^{3}$ Florida Sea Grant College Program and School of Forest Resources and Conservation, University of Florida, ${ }^{4}$ Department of Environmental and Global Health, College of Public Health and Health Professions, University of Florida, ${ }^{5}$ Aquatic Pathobiology Laboratories, Emerging Pathogens Institute, University of Florida, ${ }^{6}$ Center for Human and Environmental Toxicology, University of Florida, ${ }^{7}$ Fisheries Centre, University of British Columbia, ${ }^{8}$ Family, Youth and Community Sciences Department, University of Florida, ${ }^{9}$ Institute of Food and Agricultural Sciences, University of Florida, ${ }^{10}$ Family, Youth and Community Sciences Department and Center of Public Issues Education, University of Florida, ${ }^{11}$ Emerging Pathogens Institute, University of Florida, ${ }^{12}$ College of Medicine, University of Florida 
not only due to the Apalachicola Bay fishing community's dependence on the availability of a highly variable natural resource (oysters for fishery harvest), but also to multiple extreme regional environmental stressors. Wind, storm surge, and coastal flooding from hurricane Dennis (2005) and tropical storms Fay (2008) and Debby (2012) impacted the region. In April 2010 following the blowout of the Macondo oil well and the sinking of the Deepwater Horizon drill platform, the largest marine oil spill on record occurred in the northern Gulf of Mexico. This event had impacts on Apalachicola Bay oyster resources and the Apalachicola community (Grattan et al. 2011). Apalachicola Bay oyster fisheries were not closed to harvest during the oil spill, unlike large oyster harvesting areas in coastal Texas, Louisiana, and Alabama, because oil did not reach the Apalachicola Bay region. This initially led to increases in oyster prices and harvests to make up for shortages of oyster product in the supply chain. Harvests also increased (Pine et al. 2015) possibly because of local concerns that livelihoods could be restricted by fishery closures that might occur related to the oil spill (as reported by local fishermen). By summer 2011, consumer fears about seafood safety from the Gulf of Mexico related to the oil spill led to large

Fig. 1. Map of Apalachicola Bay, showing the location where the Apalachicola River enters the bay, the barrier islands, St. George and Little George, that enclose the bay, and the major oyster (Crassostrea virginica) bars, including two bars that have been historically productive locations for oystering: Dry Bar at the western end of the bay and Cat Point Bar just to the east of the midsection of the bay.

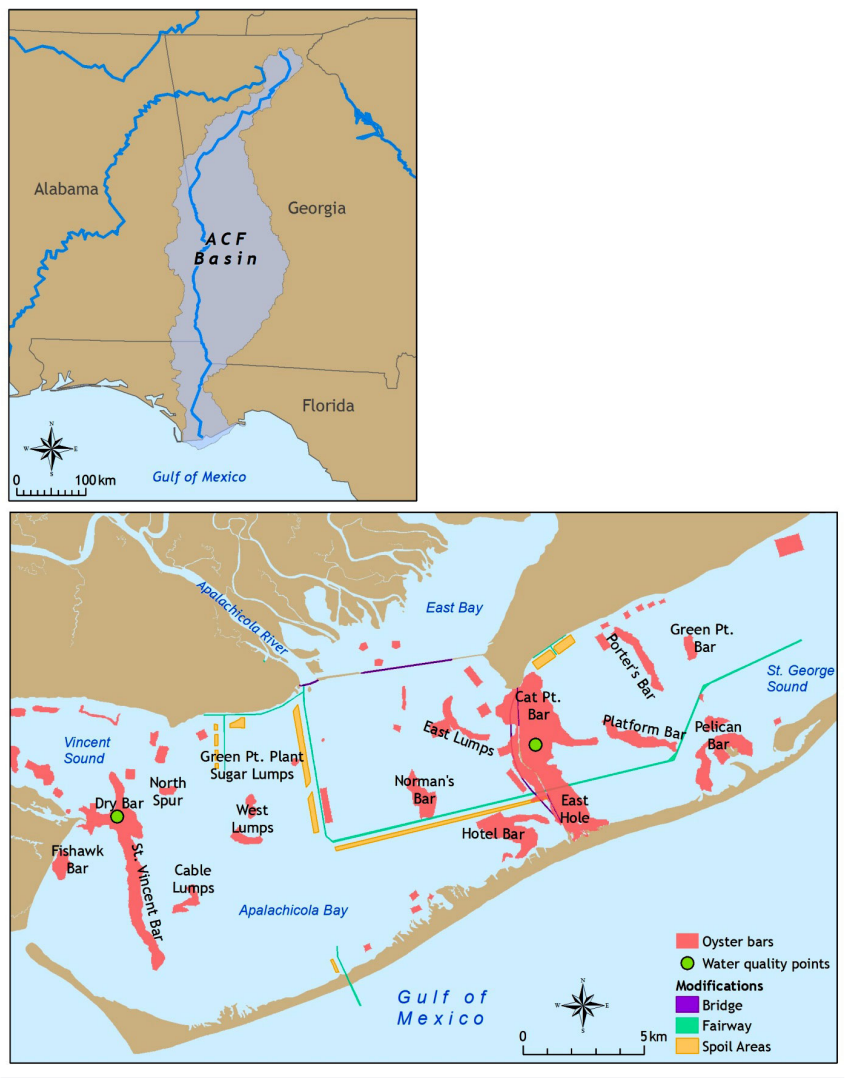

declines in seafood demand and ultimately resulted in layoffs in the regional oyster and other commercial fisheries industry, though not a cessation of oyster harvest in Apalachicola Bay (McCrea-Strub et al. 2011, Sumaila et al. 2012). These oil spillrelated events led to significant stress levels in the people living in the Apalachicola Bay area that were similar to those experienced in communities directly impacted by the oil spill (Grattan et al. 2011).

At the same time, from 2010 throughout most of 2012, drought conditions across the ACF basin led to extremely low Apalachicola River discharge, among lowest on record (S. Leitman, W. E Pine III, and G. Kiker, unpublished manuscript), and increased salinity levels in Apalachicola Bay (Havens et al. 2013). Oyster harvests and oyster fishing effort (number of trips) from Apalachicola Bay were above recent averages during this same time (Pine et al. 2015). In fall 2012, there was a sudden collapse in the Apalachicola Bay oyster fishery as harvestable oyster populations appeared to be very low. This led to reportedly significant underemployment of fishery workers and a request from the State of Florida to the National Oceanographic and Atmospheric Administration (NOAA) for a fisheries disaster declaration to allow the use of federal funds to support the industry and community during a time of disaster (Havens et al. 2013). This request was granted in 2013 (USDC 2013).

The collapse of the oyster fishery has had a profound effect on the Apalachicola Bay human community that largely depends on this fishery. Simultaneously, this community's response to the oyster population decline will likely play a prominent role in the potential recovery of the oyster population and the economic recovery of the fishery-dependent components of the community. The critical role that human communities can play in ecosystem outcomes, in this case oyster population recovery, has been well recognized (Holling 1978, Berkes and Folke 1998, Chapin et al. 2009). Increasingly research has focused on understanding the effects of community or stakeholder identification, analysis, and participation in the actual management process (Ostrom 1990, 2009 Mikalsen and Jentoft 2001). The result is a broad and growing acknowledgment that community engagement, e.g., stakeholder participation in citizen science and comanagement, is crucial to developing more effective adaptive governance systems characterized by ecosystem resilience (Holling and Meffee 1996, Folke et al. 2005, Ostrom 2009).

At the request of the county governments in the Apalachicola region, a team of researchers from the University of Florida met in 2012 with the oyster fishing industry, the Apalachicola community, and regulatory agencies to do the following: (1) identify the proximal cause of the oyster fishery collapse and (2) explore options for managing and restoring the resource to make it more resilient to future droughts and other changes. This paper describes the natural and social science aspects of the project, the major challenges faced, assessment outcomes, and management recommendations that were developed. This case study is relevant to other estuaries because it explores implementing powerful but flexible approaches to management for both natural resources and resource users (people) in a changing world, where the traditional approach of assuming and planning in the context of system stationarity is no longer applicable (Milly et al. 2008, Hallegatte 2009). 


\section{METHODS}

\section{Study site}

Apalachicola Bay is a large (63,000 ha) shallow (2.6 m mean depth) estuary located along the "Big Bend" region of the Florida panhandle, in the northeastern Gulf of Mexico. The bay is separated from the Gulf of Mexico by narrow barrier islands (Fig. 1). Much of the bay bottom is sand and soft sediment, but throughout the bay there are hard bottom areas that support oyster bars, which in turn provide habitat for other estuarine biota (Twichell et al. 2006). The major input of water to the bay is from the Apalachicola River, which drains the approximately $50,000 \mathrm{~km}^{2}$ ACF basin, one of the largest watersheds in the USA (Fig. 1).

The human population in the ACF basin is over 7 million, with the majority living near the headwaters in metropolitan Atlanta, Georgia. In the Chattahoochee and Flint River basins further downstream, there is intensive agriculture mostly supported by irrigation from groundwater withdrawals. At any given time, the amount of water entering Apalachicola Bay depends on precipitation in the basin, evapotranspiration, groundwater inputs, consumptive use from surface and subsurface sources (e.g., municipal, agricultural, industrial), and decisions by the U.S. Army Corps of Engineers (USACE) about rates of water release from the reservoirs. The relative impact of these various factors in assessing changes in river discharge has not been determined. For more than 30 years, litigation has occurred between the states of Florida, Alabama, and Georgia over water allocation within the ACF basin (CRS 2008).

The oyster industry in the Apalachicola Bay area employs over 2500 people, including fishers who harvest oysters from the bars with traditional oyster tongs (Fig. 2), and oyster dealers and seafood workers who purchase, process, and ship oysters to wholesale and retail locations across the country. It is one of the largest industries in the region. Other than changes in shipping and packing technology, the fishery has remained remarkably similar to the one first described in the early 1880 s by Swift (1898). Oysters from Apalachicola Bay are regionally known for their size and flavor characteristics. Most Apalachicola oysters are sold for the "half-shell" market, which means the oysters are kept intact and shipped as a whole product. This is important from an ecological perspective because long-term persistence of oyster bars is dependent on suitable settlement sites for growth and survival of juvenile oysters (called "spat"). Oyster shell material (live oysters and shells from dead oysters) is the most suitable substrate for oyster spat to settle and grow. If oysters and oyster shell are removed from an area at unsustainable levels, this can disrupt the "shell budget" of the population, leading to reductions in the amount of suitable habitat for oyster spat to settle and grow. To promote oyster population viability, resource managers have historically purchased shell material from other locations and deposited this shell on oyster bars open to fishing to recover lost habitat and attempt to rebalance the shell budget. The frequency and amount of "shelling" that is conducted in Apalachicola Bay is variable and dependent on funding and shell material availability (Pine et al. 2015).

Assessing recent environmental conditions in Apalachicola Bay We summarized Apalachicola River discharge patterns using measurements from the USGS Chattahoochee gauge (\#02358000, data available at http://waterdata.usgs.gov/nwis) located downstream of Jim Woodruff Dam, the furthest downstream dam in the ACF basin and the beginning of the Apalachicola River. To compare discharge levels among recent years and to examine discharge patterns since 1922 we calculated summary statistics and visually assessed patterns in monthly fresh water discharges to the bay. We assessed recent trends in water quality data maintained by the Apalachicola National Estuarine Research Reserve Lab (ANERR) for anomalous water quality patterns, such as high or low events of temperature, salinity, or dissolved oxygen (data available at http://cdmo.baruch.sc.edu/). We examined data for locations at Dry Bar, Cat Point, and subsurface and off-bottom sondes in East Bay. All data measurements for river discharge and water quality are maintained and data are quality controlled by respective management agencies.

Fig. 2. An oysterman collecting oysters (Crassostrea virginica) with a traditional pair of tongs (essentially a pair of long metal rakes connected together at midsection with a steel bolt that allows the two sections to open and close) and a close-up view of the tongs with a catch of oysters. This photo also illustrates the amount of oysters that were typically taken with one tong before the drought (the close-up) versus in 2012 (the tongs in the smaller picture). Photos by Andrew Kane.
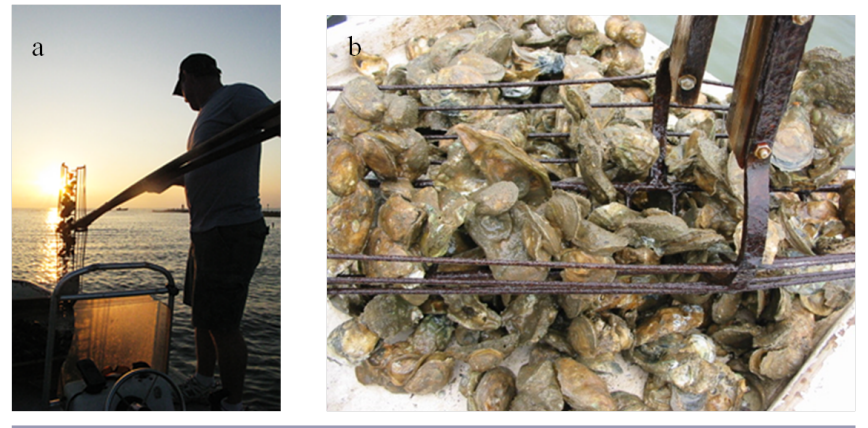

Evaluating the oyster fishery and stock status

We compiled information on trends and current oyster fishery status using fisheries dependent data from the Florida Fish and Wildlife Conservation Commission (FWC), as well as fisheriesindependent data surveys of juvenile and adult oysters collected by Florida Department of Agriculture and Consumer Services (FDACS). Prior to 1986, data on trips and landings were from a voluntary reporting program and were recorded on an annual basis. Since 1986, data were available from the FWC trip-ticket program that compiles oyster landings and trip data. We obtained 1990-2012 surveys of oyster counts by size (sublegal and legal categories) from FDACS over a wide spatial area of Apalachicola Bay. These surveys generally are completed by counting the number of oysters of different size classes inside standard quadrats on different oyster reefs throughout Apalachicola Bay. We used these size data to compile a composite average of oyster abundance across time and throughout the bay. We compiled a time series of estimated shell additions in Apalachicola Bay. These data, along with information on oyster growth rates, spawning patterns, maturity schedules, mortality rates, and other biological data obtained from previous studies, were then used to develop a stock assessment model for the Apalachicola oyster fishery (Pine et al. 2015). 


\section{Oyster health and contaminants}

Because of ongoing community concerns that the 2012 oyster population collapse was related to impacts from the Deepwater Horizon oil spill, we tested for presence of contamination associated with the oil spill by sampling oyster, finfish, blue crab (Callinectes sapidus), white shrimp (Litopenaeus setiferus), and brown shrimp (Farfantepenaeus aztecus) from multiple Apalachicola Bay locations for polycyclic aromatic hydrocarbons (PAHs). The Apalachicola Bay community specifically requested that our sampling and analysis program be done independent of state and federal agencies, which had been collecting similar samples since the oil spill as part of their own monitoring and response programs.

We also characterized prevalence and severity of the parasitic oyster disease Perkinsus marinus, which is known to cause mortality and be more prevalent under high salinity conditions (Petes et al. 2012). Perkinsus hypnospores were observed and enumerated using standardized techniques based on AshtonAlcox et al. (2006) from the same samples collected for PAH analyses. Hole-boring shell parasites were also identified and enumerated, including boring clams (Diplothyra smithii), boring sponges (Cliona spp.), and polychaete worms (Polydora spp.).

\section{Community engagement process}

Our approach to engaging the community was grounded in social vulnerability (Kelly and Adger 2000, IPCC 2001, Adger 2006) and resilience theory (Holling and Meffe 1996, Holling and Gunderson 2002), methods that have been used to look at community responses to both natural and man-made disasters (NRC 2006). Communities of people whose livelihoods are dependent on natural resources, e.g., on oysters, are particularly vulnerable to sudden and unforeseen environmental disasters (Tierney et al. 2001, Cutter et al. 2008). Resilience, i.e., the ability to withstand and absorb unexpected alterations before structural changes to the system occur (Holling 1973, Holling and Meffe 1996, Gunderson 2010), may be augmented if the human communities (stakeholders) take an active role in shaping the management of the system in a comanagement context (Holling and Gunderson 2002, Folke et al. 2005). Participation in selfgovernance requires that communities possess sufficient social capital (Portes 1998, Grafton 2005) and that these communities specifically show substantial power and legitimacy (Mikalsen and Jentoft 2001). Achieving these attributes is the task of the community itself, but development of these attributes may be facilitated by institutions that promote community participatory agreement and collaboration (Ostrom 1990, Ludwig et al. 1997, Innes and Booher 1999, Margerum 2008). This facilitation is commonly accomplished through stakeholder meetings (Grimble and Wellard 1997), multiagency and stakeholder workshops (Holling 1978), and stakeholder participation in citizen science (McCormick 2012).

We followed a community participation approach (Chambers 1994) as a way to facilitate accumulation of social capital and to ultimately bolster the community's resilience (McCormick 2012). This approach included organizing listening sessions and public forum meetings to help recognize and prioritize the concerns of the community. In our work, the goal of these events was to understand community perceptions of current problems. The first meeting was an informal listening session in October 2012; these meetings continued throughout 2014. The purpose of the first meeting was to bring interested parties together to address the oyster population decline. Participants were asked two questions: (1) what is happening, and how are these events affecting you? and (2) what do you view as potential management solutions? In subsequent meetings, constituents from the community and oyster industry helped frame the scope of the natural science research, engaged in demonstrations of an Apalachicola Bay ecosystem simulation model that was developed to support participatory decision making, and met with scientists to discuss implications of research results and management and restoration suggestions. One practical approach to immerse seafood workers in the natural science research was to train and hire a number of them as field crew to assist with logistical support in the collection of physical, chemical, and biological samples. This collaborative involvement of stakeholders in the scientific process can, in theory (Ozawa 1991, Ludwig et al. 1997) and practice (Ihde et al. 2011, McCormick 2012), promote accumulation of social capital by increasing understanding of research, building trust, and encouraging a stewardship ethic.

\section{RESULTS}

Assessing recent environmental conditions in Apalachicola Bay Freshwater discharge into Apalachicola Bay varied seasonally and annually (Fig. 3). While there have been numerous instances in the recent past with lower-than-average flow, including drought conditions in 2006 and 2007, flows at certain times in 2011 and 2012 were lower than any recorded in the last 89 years (Fig. 3 a, b). The 2011 and 2012 period of low flow had three distinctive features: (1) May-December flows were extremely low $\left(<300 \mathrm{~m}^{3}\right.$ day $\left.^{-1}\right)$; (2) there was a near absence of pulsed flow in the dry season; and (3) the conditions worsened from one year to the next. These features coincided with a persistent drought throughout the ACF basin, which was characterized by the National Integrated Drought Information System as the driest area in the USA in terms of precipitation deficit in 2011 and 2012. As an example, one part of the basin near Apalachicola experienced rainfall for ten months of 2012 that was below the lower $95 \%$ confidence interval of rainfall for the period of record from 1950 to 2011 (Fig. 3c) and most of the ACF basin was classified as severe to extreme drought (Palmer Drought Severity Index -3 or -4) during 2011-2012 (see full regional drought assessment on monthly time steps https://www.drought.gov/drought/regionalprograms/acfrb/acfrb-home).

There are limited water quality monitoring data for salinity, temperature, and dissolved oxygen in Apalachicola Bay, particularly the off-bottom monitoring representative of oyster bar conditions across a wide spatial area that would be needed to characterize salinity mixing within the bay. In the latter half of both 2011 and 2012, salinities measured by ANERR water quality monitoring stations located near a historically productive oyster bar (Cat Point) routinely were near $30 \mathrm{~g} \mathrm{~L}^{-1}$, compared to values in the 10 to $20 \mathrm{~g} \mathrm{~L}^{-1}$ range observed in earlier years with more normal river inflow (Fig. 3d).

\section{Evaluating the oyster fishery and stock status}

Monthly oyster landings of legal size oysters $(7.6 \mathrm{~cm})$ varied considerably from 2007 to 2012, with a large and persistent decline beginning in August 2012 (Fig. 4a). Coincident with this decline 
Fig. 3. River discharge (cms, panel a) at USGS Gauge 02358000 in the Apalachicola River for 2011, 2012, and 2013 (colored lines) and the median river discharge (grey shaded area). River discharge (cms) duration curve (panel b) showing river discharge exceedance from 1922-2005 (black line) and from 2007-2012 (red line). Monthly rainfall (panel c) from 2012 from the Apalachicola, Florida airport (red dots), and monthly averages and bootstrap resampled $95 \%$ confidence intervals from 1950-2012 (black circles and lines). Salinity (ppt; panel d) during 2012 measured at Cat Point by continuous water quality monitoring meters located near the surface of Apalachicola Bay and maintained by Apalachicola National Estuarine Research Reserve Lab staff.
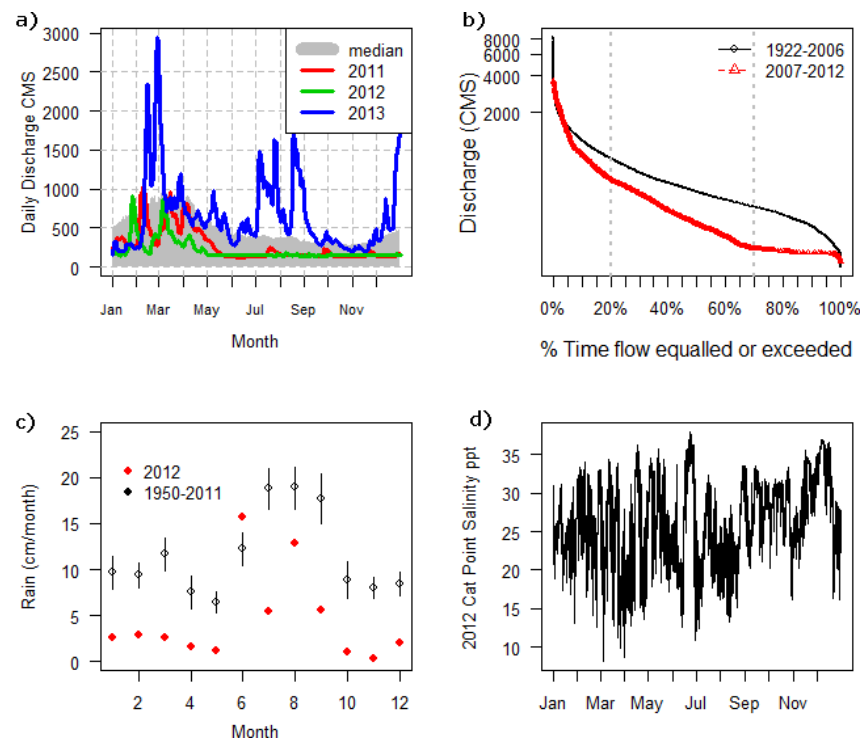

were downward trends in the densities of sublegal and legal size oysters measured in fishery independent transect sampling from several oyster bars (Fig. 4b). This was preceded by an increase in license holders and fishing effort (number of trips) in the years prior to the collapse, leading to initial speculation of a classic case of overfishing leading to the collapse of the Apalachicola oyster fishery in 2012. However, detailed analyses of available data was inconclusive as to whether overfishing had occurred (Pine et al. 2015). Collections of historical data revealed shelling activities as a restoration strategy have varied widely in recent decades depending on funding and availability of materials (Pine et al. 2015).

\section{Oyster health and contaminants}

Concomitant with the period of high salinity in 2012 and decline in sublegal oyster densities, oysters collected from the bay displayed parasitism by a variety of organisms (Fig. 5). The prevalence and severity of Perkinsus marinus infection was monitored in oysters from several bay locations. Perkinsus infection severity observations from 2012 and 2013 revealed similar or slightly higher weighted severity prevalence scores $(1.00$ to 1.33 ) compared with sporadic data from the past 10 years (0.66). It should also be noted that seafood workers collaborating with our research commented on the high abundance of
Fig. 4. Monthly landings (a) data from the Florida Fish and Wildlife Conservation Commission, indicating reported amounts of oysters (Crassostrea virginica) harvested in 1000s $\mathrm{kg} / \mathrm{month}$, and oyster abundance from Florida Department of Agriculture and Consumer Services fisheries-independent surveys of oyster bars (b), indicating densities of both legal (> $7.6 \mathrm{~cm})$ and sublegal sized oysters ( $\mathrm{m} 2 / \mathrm{month})$. In both panels, the 2012 data are provisional.
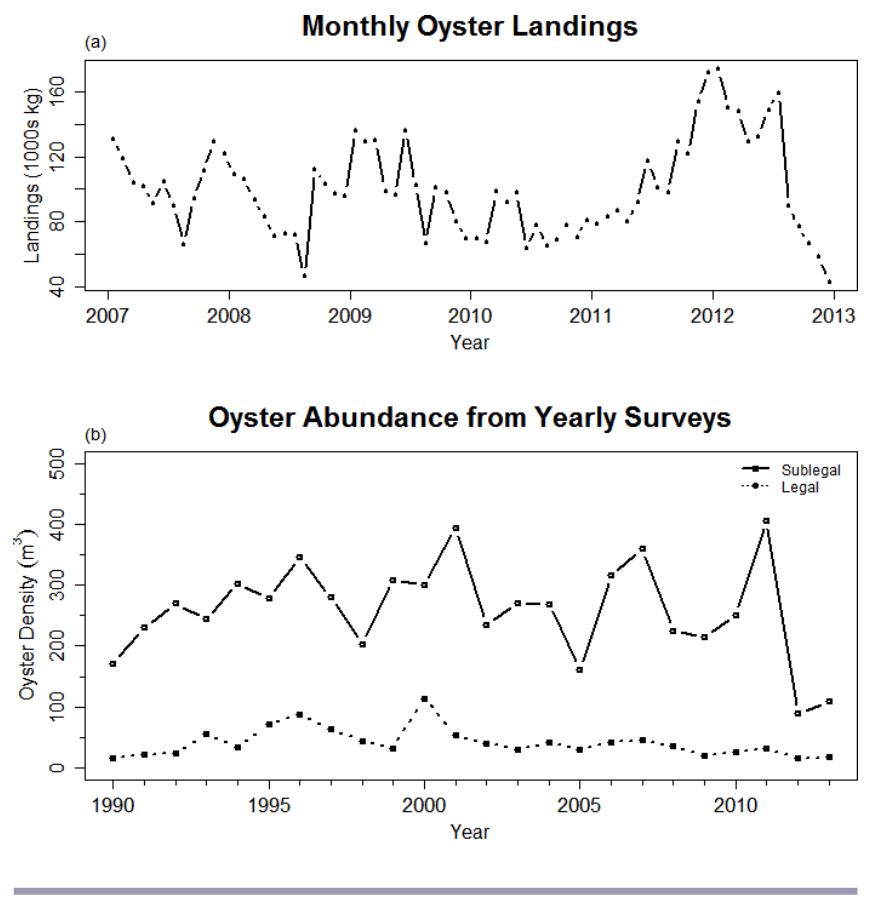

gastropod oyster predators including oyster drills (Stramonita haemostoma) in Apalachicola Bay during 2011-2013, but no time series of abundance of oyster predators is available in which to verify this observation or place it in context of historical predation levels. Analytical toxicology of edible portions of oyster, finfish, crab, and shrimp did not reveal above-background concentrations of PAH parent compounds or their alkylated homologs (Kane et al. 2015).

\section{Community engagement process}

To date, four community meetings were held that directly related to this work. Detailed quantitative and demographic information of participants was not collected for any meetings. Outputs from community meetings and stakeholder engagement indicated several important community perceptions surrounding the collapse of the oyster fishery. The community identified difficulty in accessing clear and reliable information on the status and trends in oyster populations, as well as information on the overall health of Apalachicola Bay. The stakeholder community generally appeared to have a lack of trust in governmental agencies that are perceived as responsible for managing Apalachicola Bay resources and felt that these agencies were not sharing information with the community. Community members also expressed a strong desire to collaborate with scientists to obtain information needed to understand the oyster fishery collapse. It was also recognized that the community itself has some responsibility for 
Fig. 5. Shell parasites observed in Apalachicola Bay oysters 2012-2013. The whole oyster (Crassostrea virginica) shell on the left shows evidence of several types of parasite damage. The blue arrow points to one of several larger holes formed by a boring clam (Diplothyra smithii). Also evident are numerous smaller holes associated with the boring sponge, Cliona spp. The panels to the right show close up images of common oyster shell parasites. Panel A shows two boring clams seen at the edge of a shell that was fractured to reveal the parasites. Note the black spot (yellow arrow) associated with the clam's activity on the inner nacreous layer of the shell. Panel B shows close up of exterior shell holes bored by Cliona sponge. In life, this sponge organism is yellow and protrudes from the shell holes (Panel C). Panel D reveals a Polydora polychaete worm on the outside of the shell. This worm forms tubes within the shell, and can cause the oyster host to wall off this invader by laying down nacreous shell on the inside of the shell, sometimes causing "mud blisters." Photos by Andrew Kane.

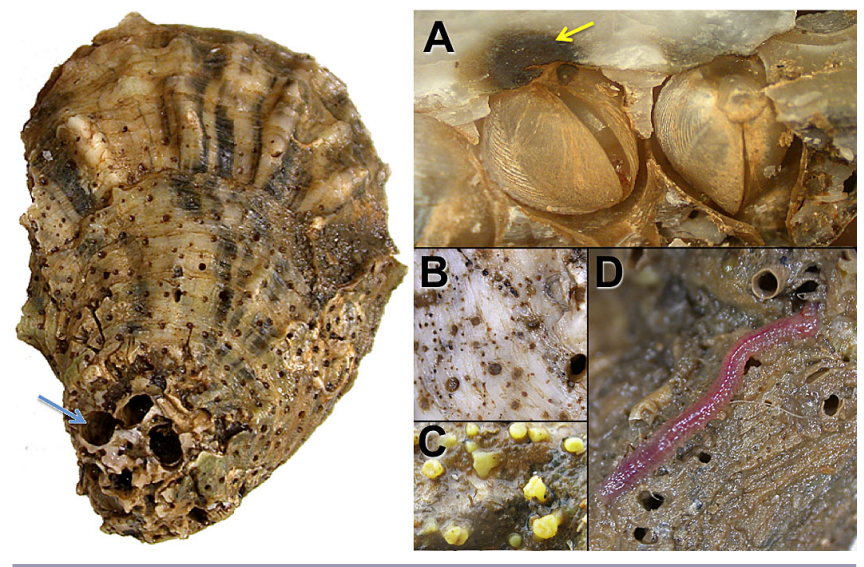

the current status of the oyster fishery. However, these perceptions cannot be generalized to the Apalachicola population as a whole because meeting attendance was self-selected and not randomized.

In addition to these perceptions, community members introduced a community collaborative initiative to facilitate information exchange among the Apalachicola Bay oyster fishing community. This stakeholder-based community initiative, named the Seafood Management Assistance Resource Recovery Team (SMARRT), was formed with the objective of collaboratively addressing current hardships brought on from the collapse of the oyster fishery and the cumulative stress of multiple events impacting the oyster fishing community in recent years. SMARRT governance was not explicitly defined, but membership includes multiple resource user groups in Apalachicola Bay including oyster, fish, crab, and shrimp fishers; recreational charter fishing guides; and wholesale seafood buyers. Regulatory agencies, government officials, retail seafood businesses, nonprofit organizations, and social service and academic institutions are in partnership with SMARRT, but do not have voting privileges. The SMARRT group can be considered as a stakeholder-led approach intended to augment "inherent resilience" of the community to respond to this and other (unforeseen) future disruptive events (Adger et al. 2005, Colten et al. 2012).

\section{DISCUSSION}

\section{Changes and stressors to the Apalachicola Bay system}

Why did the oyster fishery collapse in Apalachicola Bay Florida during 2012? Although a detailed assessment of the dependent and independent data was not able to identify a specific proximal cause (Pine et al. 2015), it is considered likely that a sequence of events occurred whereby: (1) low river flow led to increased salinity in Apalachicola Bay for a multiyear period; (2) which likely led to increases in oyster parasites, predators, or unknown pathogens; (3) causing elevated mortality, particularly among juvenile oysters; (4) which led to recruitment failure, potentially exacerbated by shell removal from fishing or environmental events; and then (5) population collapse of adult oysters. There is no evidence that contaminants associated with the 2010 Deepwater Horizon oil spill in the Gulf of Mexico contributed to the collapse.

Our proposed multiple reasons for the 2012 collapse are not unlike earlier observations for Apalachicola Bay and other oyster fisheries. In general, declines and collapses of oyster fisheries and oyster mortality events have been associated with multiple drivers, including overfishing, disease, structural habitat loss, hypoxia, and changing salinity regimes (Lenihan and Peterson 1998, Wilberg et al. 2011). Specifically in Apalachicola Bay, Petes et al. (2012) examined Perkinsus frequency during drought years 2007 and 2008 and found higher oyster mortality rates with higher salinity levels. Ford and Tripp (1996) noted that Perkinsus primarily impacts oysters in their second year of life (approximate age of legal size in Apalachicola Bay in some years). Menzel et al. (1966) documented increased abundance of oyster predators including oyster drills and stone crabs (Menipe mercenaria) on higher salinity oyster bars in Apalachicola Bay during drought conditions in 1955-1957. During this time period, oyster reefs with highest predator abundances were "depleted" but the abundance of these predators declined when drought ended and salinities returned to normal, and the depleted oyster reefs later returned to productive levels (Menzel et al. 1966). Livingston et al. (1997) noted widespread changes in trophic structure in Apalachicola Bay resulting from low river flow, and attributed this largely to the reduced nutrient input and lowered primary productivity and these changes have been observed over more than 30 years (Livingston 2002, 2015). Livingston et al. (1997:294) concluded that "with reduction of fresh water flow below a level specific for the receiving system, the physically controlled, biologically productive river-estuarine system could become a species-rich, biologically controlled bay with substantially reduced productivity." Although we cannot pinpoint the cause of the oyster collapse, because we were not conducting research in the bay when the event occurred, it is likely related to a combination of factors such as these observed in earlier research efforts and periods of low oyster abundance (Livingston 2015).

Some of the changes and potential stressors to this system are likely to continue. Changing fresh water inflow, for example, will probably be a persistent issue, and has had documented effects on many ecosystems globally (Visser et al. 2002, Buzan et al. 2009, Elsdon et al. 2009, Govender et al. 2011, Bucater et al. 2013). Although some stresses, e.g., oil spills, may not soon be repeated (although the risk may be increasing with expanded oil development in the Gulf of Mexico), other one-off and 
inherently unpredictable disturbances, e.g., economic depressions or hurricanes, are certain to occur (Carpenter et al. 1999). The high probability of unpredictable future change motivates the implications of our work to be directed across a range of temporal scales. Immediate restoration plans may be useful for ameliorating damage caused in the most recent oyster decline, for which causes remain uncertain. At a minimum, monitoring of restoration activities is required to assess their efficacy and hopefully improve environmental knowledge of the system via episodic learning (Gunderson 2010). Such knowledge may be further improved if adaptive management practices are embraced, allowing empirical evaluation of oyster fishery responses to controllable elements, e.g., shelling or enhanced property rights. In addition, because of irreducible uncertainty but inevitability of future perturbations (Carpenter et al. 1999), long-term system resilience should be augmented through steps taken to improve the flexibility and adaptability of the governance, including self-governance, of these systems.

\section{Restoration and planning actions to promote resilience in the Apalachicola oyster fishery}

Given the numerous ways in which reduced freshwater flow can affect estuaries ranging from declines in species abundance to trophic reorganization, a variety of responses have been proposed for coastal ecosystems particularly in the context of climate change and potential extreme weather events (Christensen et al. 2007, Meehl et al. 2007). Wetz and Yoskowitz (2013) developed a conceptual model that linked changes in climate with changes in the physical and chemical state of estuaries with biological responses and ultimately goods and services provided by these ecosystems. These researchers caution that the combined effects of extreme climatic events co-occurring with climate variability, global warming, and sea level rise may impact ecosystems and human users in numerous ways ranging from declines in coastal fisheries to tourism, both of which would have large economic impacts on many communities. Because estuaries provide such a wide array of ecosystem services, a future with prolonged periods of high stress on estuarine ecosystems could have widespread deleterious effects to these ecosystems and their human users (Costanza et al. 1997, Hobbie 2000, Yoskowitz et al. 2010).

There is a need to understand how climate, drought, and other extreme weather events are related to estuarine goods and services to promote restoration and management actions, and ultimately, resilience. For example, a natural salinity gradient exists in Apalachicola Bay with lower salinity levels close to the river mouth and increasing salinity away from the Apalachicola River. This creates a natural experimental gradient to examine how oyster recruitment, disease dynamics, and oyster predator communities within the bay relate to different salinity levels, one of our hypothesized mechanisms contributing to the oyster population collapse in 2012. Pine et al. (2015) developed a population dynamics model that can be used to screen different restoration strategies for oysters in Apalachicola Bay using a combination of shelling and harvest regulations. Iteratively combining information from detailed monitoring (observations) with predictions from this type of population model is an effective framework for learning and informing management and restoration strategies (Pine et al. 2009). This type of monitoring and modeling framework is essential to resolve persistent uncertainties and develop an understanding of the complex relationships between fresh water flow and ecosystem responses in Apalachicola Bay.

Recognition of the uncertainties between river discharge and ecosystem responses could refocus research, management, and community engagement efforts on strategies that maximize the potential for learning about the system and bolstering management options, while simultaneously augmenting the resilience of the system to withstand future surprises (Holling 1978, Walters 1986, Gunderson 2010). To reach these broad goals we suggest (1) a series of minimal best management practices designed to sustain the social-ecological system in the near future, (2) plans for improving knowledge of the environmental and sociological system through adaptive management and experimentation, and (3) steps to help create adaptive governance institutions capable of interpreting updated environmental information and responding to changes before collapse of the system.

\section{Minimal best management practices}

One of the most immediate management decisions impacting this system is how to use available restoration funding. Currently there is US\$10 million or more in funding committed from a variety of sources, mostly related to restitution and penalties resulting from the Deepwater Horizon oil spill, for restoration activities in Apalachicola Bay. Proposed or ongoing restoration actions are primarily related to rehabilitating depleted oyster bars through the addition of shell material to serve as nucleation substrate for oyster recruitment and growth. When combined with restrictive fishing practices this type of restoration has delivered short-term success in Apalachicola Bay in the past, following Hurricane Elena in the early 1980s (Berrigan 1990). The current proposed restoration need is much larger than in the past and oyster responses to both shelling and continued harvest are uncertain. Two questions that must be immediately addressed are (1) how to maximize effectiveness of shell material additions as a restoration technique, i.e., location and density of shell additions, and (2) how much harvest should be permitted concomitant to such restoration efforts. Although shell additions have occurred for decades in Apalachicola Bay, and shelling density is directly related to reef height and physical attributes that have been related to oyster mortality (Lenihan and Peterson 1998, Gregalis et al. 2008), the functional relationship between the density of shelling and resultant oyster recruitment is not well known for this region or beyond (La Peyre et al. 2014). Depending on this relationship, it is possible that restoration actions with shell material may not be effective if the target area for restoration is shelled at too sparse a level or is shelled at an unnecessarily high density (Schulte et al. 2009). Further, if substantial shell substrate habitats have been lost in Apalachicola Bay (from storm events or reduced production of natural shell owing to low recruitment or oyster and oyster shell harvest) then the risk of the oyster fishery having negative effects on the oyster population has likely increased (Pine et al. 2015). This is because the loss of shell likely creates a negative feedback cycle between the oysters that are harvested, the shell that is available as substrate for oyster settlement, and the number of oyster recruits produced each year (Pine et al. 2015). Although this feedback may not be strong in years with high oyster abundance (which creates high shell abundance), in years with 
low live oyster or shell abundance, the interactions between oyster spat, substrate, and adult harvests may be strong.

Although restricting oyster harvests through fishery closures may intuitively decrease the risk of oyster population collapse, Pine et al. (2015) found that if oyster recruitment remains low then restricting oyster harvests has little impact on oyster population recovery. However, closing the oyster fishery would certainly exacerbate the immediate hardships experienced by the oyster fishing community through increased underemployment. Employing oyster fishers to participate in restoration programs when logistically and fiscally possible is currently a centerpiece in some proposed restoration programs. Given the uncertainty regarding the density of shelling and the effects of drought and oyster harvest on restoration effectiveness, any restoration actions should include a matrix of oyster reefs restored at different shell densities, at different salinity levels, and available for harvest at different times. This type of design, combined with maximizing area restored by minimizing restoration costs (through a combination of employing fishers based in small boats, and contractors using large barges) should provide key learning to inform restoration actions increasing the likelihood of restoration success (Gunderson 2010, La Peyre et al. 2014).

In addition to restoration actions, we recommend the evaluation of Territorial User Rights Fisheries (TURF; Prince et al. 1998) for oyster resources where fishers would transition from common users of public oyster reefs to becoming "farmers" of leased areas in Apalachicola Bay. This regulatory structure has several potential advantages over the current open access fishery. First, lease holders may economically benefit from the freedom to determine when and at what size to harvest oysters on their TURF without concern that other fishers would harvest oysters first, i.e., tragedy of the commons. This approach would also provide incentives for increased stewardship of the resource by promoting careful management of available shell material or employing practices to minimize mortality losses from predators through the use of cover netting as a predator exclusion device, such as used in the hard clam culture industry in Florida. A TURF system could have negative consequences for recreational oyster fishers where they are prominent; however, the majority of oyster fishing effort in Apalachicola is commercial and managers could likely set aside some regions for recreational oyster fishing. Combined, potential benefits from such a TURF system may increase the inherent community resilience of the system, by enhancing the practical capacity to cope with disruption (Colten et al. 2012).

\section{Improved system knowledge}

Changing climate will potentially increase the frequency or severity of a variety of Apalachicola Bay stressors, including droughts, and storm frequency or severity, all of which are factors thought to strongly influence Apalachicola Bay oyster populations. Identifying the most critical ecosystem stressors that influence oyster population viability and that can be influenced by management is essential to informing proposed restoration programs to promote long-term resilience. Identifying these critical stressors can best be accomplished through structured, objectivedriven management experiments, e.g., active adaptive management (La Peyre et al. 2014). For example, key uncertainties related to Apalachicola River discharge and oyster recruitment could be resolved through a coupled monitoring program of salinity, river discharge, and oyster spat sampling at multiple locations in Apalachicola Bay over several years. Environmental conditions in recent years (2012-2014) represent a strong contrast in Apalachicola River discharge conditions that could have provided significant insight if detailed monitoring programs had been in place. Uncertainty related to the effects of fishing on oyster reefs (through harvest and loss of shell material) could be assessed through pre- and postfishing season assessments of oyster reef shell density and oyster recruitment as compared to similar reefs that are closed to fishing. These types of research efforts could simultaneously inform the restoration of critical ecosystem services while providing valuable knowledge of how the system functions and how future stressors can be practically addressed.

Improving knowledge and understanding of stakeholders and their dynamics is also critical to future resilience of the Apalachicola Bay oyster fishery. Stakeholder perceptions are not currently well understood. Although some perceptions and attitudes were described in this and other studies (Grattan et al. 2011), assessments of stakeholder opinions of, investment and participation in management are largely unknown, as are how the same stakeholder characteristics may be mediated by future environmental change and management actions. Given the importance of stakeholder involvement in system resilience, improving understanding of stakeholder functional responses is critical (Ostrom 2009, Gunderson 2010). Monitoring stakeholder perceptions and actions could be considered an explicit objective and integrated with environmental monitoring and adaptive management designs. Such an approach might afford accelerated learning through the systematic probing of adaptive management (Walters 1986) and promote rediscovery and transmission of traditional stakeholder knowledge of themselves and the system (Berkes et al. 2000) while facilitating the broader range of participation and detection of system changes possible through citizen science (McCormick 2012). This approach to improving understanding of stakeholders could be implemented through multiple actions. Regular stakeholder meetings can be established in the Apalachicola Bay oyster fishery community. Meetings can serve to (1) encourage the transfer of information and ideas from stakeholder to researchers and managers and vice versa and (2) facilitate temporal monitoring of stakeholder perceptions correlated to changing environmental conditions and management actions. Analyses of the latter will requires recording more information than was done for this study, specifically overall attendance and individual information, to allow appropriate accounting of temporal and random effects. A small and likely nonrandom proportion of the community will attend such meetings, so community-wide inferences will depend on relating information gleaned at such meetings to the broader population. This can be well accomplished by pairing periodic surveys at meetings with general fishery surveys distributed by mail and email. If the objectives of these stakeholder studies are translucently communicated, critical information can hopefully be recovered without a loss of stakeholder trust.

Although future environmental effects of climate change are almost certain, learning how the social-ecological system responds to environmental changes and management actions is key to maximizing episodic learning opportunities afforded by this disaster (Gunderson 2010). Learning is likely to be maximized through implementation of an active adaptive management and 
monitoring framework, both of the oyster populations and stakeholders. Information gleaned from this framework can be used to inform conceptual and quantitative system models to update best management practices. This will support balancing system performance and learning while theoretically increasing resilience.

\section{Adaptive governance institutions}

Livingston $(2002,2015)$ conducted studies over four decades of research in Apalachicola Bay with the purpose of documenting long-term patterns and interactions in a huge variety of biotic and abiotic processes. This research was designed to promote resource conservation and inform management actions and ultimately led to the development of a regional management plan to protect resources in Apalachicola Bay. This tremendous effort resulted in dozens of manuscripts and two books synthesizing research findings (Livingston 2002, 2015). Even with the substantial efforts and learning documented through this work, Livingston (1991:361) states that "well-conceived management plans can be reversed by political manipulations and short-sighted bureaucratic policies." It is worth considering how these same mistakes may be avoided in the present situation.

We recognize that our recommendations for immediate management practices and future learning opportunities, e.g., scientifically designed monitoring of shell addition, are of little benefit toward system resilience without governance institutions capable of timely processing of this information and adaption of updated management strategies (Holling and Meffe 1996, Gunderson 2010). Adaptive governance requires cooperation among institutional politicians, managers, and scientists (Grafton 2005, Walters 2007), as well as stakeholders possessing the social capital to participate in comanagement (Ostrom 1990, 2009, Grafton et al. 2007, Gunderson 2010). In many social-ecological systems, including the Apalachicola oyster fishery, accomplishing this level of cooperation represents one of the greatest challenges and uncertainties. One path we recommend to augment both intergovernance cooperation and stakeholder participation in management is to proceed with workshops (Holling 1978, Walters 1986, McCormick 2012) that bring together managers, scientists, and community groups, such as SMARRT. This approach strengthens formal and informal networks and facilitates development of social learning platforms that can foster collaboration to produce a united front to interact with policy makers. A central component to this collaboration is the construction of quantitative models that describe how the system works, upon which stakeholders and governance components can explicitly compare their assumptions of the system and its response to management strategies. This type of model is most useful as a tool to initiate meaningful and specific conversation about management options. It is this conversation that is critical and often missing in systems struggling to attain adaptive, comanaged governance institutions.

\section{CONCLUSIONS}

Global trends in climate and human populations suggest that associated stresses to estuaries are likely to continue, and that future social-ecological disasters should be expected. Although increased environmental knowledge may aid in prevention of some catastrophic events, complete avoidance is not possible because the drivers of these events usually cannot be identified. We believe that learning how social-ecological systems function must be combined with efforts to augment the adaptability of the governance of these systems. Such attempts to reduce environmental uncertainty and develop community capacity and resilience, while simultaneously acknowledging uncertainty in decision-making processes, are critical to the resilience of these complex social-ecological systems.

We did not study or reach any conclusions about any effect of water withdrawals from the aquifer affecting the Apalachicola River Basin or oyster populations in Apalachicola Bay. This is an area that warrants future research.

Responses to this article can be read online at: http://www.ecologyandsociety.org/issues/responses. $\mathrm{php} / 7821$

\section{Acknowledgments:}

The authors are grateful to the agencies that provided data that supported our analyses, including the Florida Department of Agriculture and Consumer Services, the Florida Fish and Wildlife Conservation Commission, the Florida Department of Environmental Protection, and the Northwest Florida Water Management District. Susan Marynowski provided expert editorial guidance. This work was supported by the University of Florida Institute of Food and Agricultural Sciences, by the National Sea Grant College Program of the U.S. Department of Commerce's National Oceanic and Atmospheric Administration (NOAA Grant Number NA10-OAR4170079), and a grant from the National Institute of Environmental Health Sciences (NIEHS Grant Number U19ES020683) as part of the Deepwater Horizon Research Consortium. The views expressed by the authors do not necessarily reflect the views of NOAA, FFWCC, or the NIEHS.

\section{LITERATURE CITED}

Adger, W. N. 2006. Vulnerability. Global Environmental Change 16:268-281. http://dx.doi.org/10.1016/j.gloenvcha.2006.02.006

Adger, W. N., T. P. Hughes, C. Folke, S. R. Carpenter, and J. Rockström. 2005. Social-ecological resilience to coastal disasters. Science 309:1036-1039. http://dx.doi.org/10.1126/science.1112122

Ashton-Alcox, K. A., Y. Kim, and E. N. Powell. 2006. Perkinsus marinus assay. Pages 153-164 in Y. Kim, K. A. Ashton-Alcox, and E. N. Powell, editors. Histological techniques for marine bivalve mollusks: Update. NOAA Technical Memorandum NOS NCCOS 27. Silver Spring, Maryland, USA.

Barbier, E. B., S. D. Hacker, C. Kennedy, E. W. Koch, A. C. Stier, and B. R. Silliman. 2011. The value of estuarine and coastal ecosystem services. Ecological Monographs 81:169-193. http://dx. doi.org/10.1890/10-1510.1

Berkes, F., J. Colding, and C. Folke. 2000. Rediscovery of traditional ecological knowledge as adaptive management. Ecological Applications 10:1251-1262. http://dx.doi.org/10.1890/1051-0761 (2000)010[1251:roteka]2.0.co;2 
Berkes, F., and C. Folke. 1998. Linking social and ecological systems for resilience and sustainability. Page 13-20 in F. Berkes, and C. Folke, editors. Linking social and ecological systems. Cambridge University Press, Cambridge, UK.

Berrigan, M. E. 1988. Management of oyster resources in Apalachicola Bay following Hurricane Elena. Journal of Shellfish Research 7:281-288.

Berrigan, M. E. 1990. Biological and economical assessment of an oyster resource development project in Apalachicola Bay, Florida. Journal of Shellfish Research 9(1):149-158.

Bucater, L. B., J. P. Livore, C. J. Noell, and Q. Ye. 2013. Temporal variation of larval fish assemblages of the Murray Mouth in prolonged drought conditions. Marine and Freshwater Research 64(10):932-937. http://dx.doi.org/10.1071/mf12278

Buzan, D., W. Lee, J. Culbertson, N. Kuhn, and L. Robinson. 2009. Positive relationship between freshwater inflow and oyster abundance in Galveston Bay, Texas. Estuaries and Coasts 32:206-212. http://dx.doi.org/10.1007/s12237-008-9078-Z

Carpenter, S., W. Brock, and P. Hanson. 1999. Ecological and social dynamics in simple models of ecosystem management. Conservation Ecology 3(2):4.

Chambers, R., 1994. The origins and practice of participatory rural appraisal. World Development 22:953-969. http://dx.doi. org/10.1016/0305-750X(94)90141-4

Chapin, F. S., G. P. Kofinas, and C. Folke. 2009. Principles of ecosystem stewardship. Springer, New York, New York, USA.

Christensen, J. H., B. Hewitson, A. Busuioc, A. Chen, X. Gao, I. Held, R. Jones, R. K. Kolli, W.-T. Kwon, R. Laprise, V. MagañaRueda, L. Mearns, C. G. Menéndez, J. Räisänen, A. Rinke, A. Sarr, and P. Whetton. 2007. Regional climate projections. Pages 849-940 in S. Solomon, D. Qin, M. Manning, Z. Chen, M. Marquis, K. B. Averyt, M. Tignor, and H. L. Miller, editors. Climate change 2007: The physical science basis. Contribution of working group I to the fourth assessment report of the intergovernmental panel on climate change. Cambridge University Press, Cambridge, UK.

Colten, C. E., J. Hay, and A. Giancarlo. 2012. Community resilience and oil spills in coastal Louisiana. Ecology and Society 17(3): 5. http://dx.doi.org/10.5751/es-05047-170305

Congressional Research Service (CRS). 2008. Report for congress: Apalachicola-Chattahoochee-Flint ( $A C F)$ drought: Federal water management issues. United States Congressional Research Service, Washington, D.C., USA.

Costanza, R., R. d'Arge, R. de Groot, S. Farber, M. Grasso, B. Hannon, K. Limburg, S. Naeem, R. V. O’Neill, J. Paruelo, R. G. Raskin, P. Sutton, and M. van den Belt. 1997. The value of the world's ecosystem services and natural capital. Nature 387:253-260. http://dx.doi.org/10.1038/387253a0

Cutter, S. L., L. Barnes, M. Berry, C. Burton, E. Evans, E. Tate, and J. Webb. 2008. A place-based model for understanding community resilience to natural disasters. Global Environmental Change 18:598-606. http://dx.doi.org/10.1016/j.gloenvcha.2008.07.013
Elsdon, T. S., M. B. N. A. de Bruin, N. J. Diepen, and B. M. Gillanders. 2009. Extensive drought negates human influence on nutrients and water quality in estuaries. Science of the Total Environment 407:3033-3043. http://dx.doi.org/10.1016/j. scitotenv.2009.01.012

Folke, C., T. Hahn, P. Olsson, and J. Norberg. 2005. Adaptive governance of social-ecological systems. Annual Review of Environmental Resources 30:441-473. http://dx.doi.org/10.1146/ annurev.energy.30.050504.144511

Ford, S. E., and M. Tripp. 1996. Diseases and defense mechanisms. Pages 560-581 in V. S. Kennedy, I. E. Newell, and A. F. Eble, editors. The eastern oyster: Crassostrea virginica. Maryland Sea Grant, College Park, Maryland, USA.

Govender, N., A. J. Smit, and R. Perissinotto. 2011. Trophic functioning of the St. Lucia estuarine lake during a drought phase assessed using stable isotopes. Estuarine, Coastal and Shelf Science 93:87-97. http://dx.doi.org/10.1016/j.ecss.2011.02.019

Grabowski, J. H., and C. H. Peterson. 2007. Restoring oyster reefs to recover ecosystem services. Theoretical Ecology Series 4:281-298. http://dx.doi.org/10.1016/s1875-306x(07)80017-7

Graeff, T., G. Baroni, A. Bronstert, C. Brunk, I. Martinez, and S. Oswald. 2013. Modelling changing hydrology in a coastal area under the influence of climatic change until 2100. Geophysical Research Abstracts 15:EGU2-13-12559.

Grafton, R. Q. 2005. Social capital and fisheries governance. Oceans and Coastal Management 48:753-766. http://dx.doi. org/10.1016/j.ocecoaman.2005.08.003

Grafton R. Q., T. Kompas, R. McLoughlin, and N. Rayns. 2007. Benchmarking for fisheries governance. Marine Policy 31:470-479. http://dx.doi.org/10.1016/j.marpol.2006.12.007

Grattan, L. M., S. Roberts, W. T. Mahan Jr, P. K. McLaughlin, W. S. Otwell, and J. G. Morris Jr. 2011. The early psychological impacts of the Deepwater Horizon oil spill on Florida and Alabama communities. Environmental Health Perspectives 119 (6):838-843. http://dx.doi.org/10.1289/ehp.1002915

Gregalis, K. C., S. P. Powers, and K. L. Heck Jr. 2008. Restoration of oyster reefs along a bio-physical gradient in Mobile Bay, Alabama. Journal of Shellfish Research 27:1163-1169. http://dx. doi.org/10.2983/0730-8000-27.5.1163

Grimble, R., and K. Wellard. 1997. Stakeholder methodologies in natural resource management: a review of principles, contexts, experiences and opportunities. Agricultural Systems 55:173-193. http://dx.doi.org/10.1016/S0308-521X(97)00006-1

Gunderson, L. 2010. Ecological and human community resilience in response to natural disasters. Ecology and Society 15(2): 18. [online] URL: http://www.ecologyandsociety.org/vol15/iss $2 /$ $\underline{\operatorname{art} 18}$

Hallegatte, S. 2009. Strategies to adapt to an uncertain climate change. Global Environmental Change 19(2):240-247. http://dx. doi.org/10.1016/j.gloenvcha.2008.12.003

Havens, K., M. Allen, E. Camp, T. Irani, A. Lindsey, J. G. Morris, A. Kane, D. Kimbro, S. Otwell, B. Pine, and C. Walters. 2013. 
Apalachicola Bay oyster situation report. Technical Publication 201. University of Florida Sea Grant, Gainesville, Florida, USA.

Hobbie, J. E. 2000. Estuarine sciences: a synthetic approach to research and practice. Island Press, Washington, D.C., USA.

Holling, C. S. 1973. Resilience and stability of ecological systems. Annual Review of Ecology and Systematics 4:1-23. http://dx.doi. org/10.1146/annurev.es.04.110173.000245

Holling, C.S., 1978. Adaptive environmental assessment and management. Blackburn Press, Caldwell, New Jersey, USA.

Holling, C. S., and L. H. Gunderson. 2002. Resilience and adaptive cycles. Island Press, Washington, D.C., USA.

Holling, C. S., and G. K. Meffe, 1996. Command and control and the pathology of natural resource management. Conservation Biology 10:328-337. http://dx.doi.org/10.1046/j.1523-1739.1996.10020328. $\underline{\mathrm{x}}$

Ihde, T. F., M. J. Wilberg, D. H. Secor, and T. J. Miller. 2011. FishSmart: harnessing the knowledge of stakeholders to enhance U.S. marine recreational fisheries with application to the Atlantic king mackerel fishery. Pages 75-93 in T. D. Beard, R. Arlinghaus, and $\mathrm{S}$. G. $\mathrm{Su}$, editors. The angler in the environment: social, economic, biological, and ethical dimensions. Proceedings of the 5th world recreational fishing conference. American Fisheries Society, Herndon, Virginia, USA.

Ingram, W. 2013. Some implications of a new approach to the water vapour feedback. Climate Dynamics 40(3):925-933. http:// dx.doi.org/10.1007/s00382-012-1456-3

Innes, J. E., and D. E. Booher. 1999. Consensus building and complex adaptive systems: a framework for evaluating collaborative planning. Journal of the American Planning Association 65:412-423. http://dx.doi.org/10.1080/01944369908976071

Intergovernmental Panel on Climate Change (IPCC). 2001. Climate change 2001: impacts, adaptation and vulnerability. Contribution of Working Group II to the Third Assessment Report of the Intergovernmental Panel on Climate Change. J. J. McCarthy, O. F. Canziani, N. A. Leary, D. J. Dokken, and K. S. White, editors. Cambridge University Press, Cambridge, UK.

Kane, A. S., J. Munson, M. O. James, E. B. Overton, M. Kozuch, R. M. Brooks, N. G. Odezulu, and S. M. Roberts. 2015. Analytical toxicology of PAHs from inshore-harvested seafood from the Gulf of Mexico: studies to support seafood safety postDeepwater Horizon oil spill. The Toxicologist: Supplement to Toxicological Sciences 144(1):29.

Kelly, P. M., and W. N. Adger. 2000. Theory and practice in assessing vulnerability to climate change and facilitating adaptation. Climatic Change 47:325-352. http://dx.doi. org/10.1023/A:1005627828199

La Peyre, M., J. Furlong, L. A. Brown, B. P. Piazza, and K. Brown. 2014. Oyster reef restoration in the northern Gulf of Mexico: extent, methods and outcomes. Ocean and Coastal Management 8:20-28. http://dx.doi.org/10.1016/j.ocecoaman.2013.12.002

Lenihan, H. S., and C. H. Peterson. 1998. How habitat degradation through fishery disturbance enhances impacts of hypoxia on oyster reefs. Ecological Applications 8:128-140. http:// dx.doi.org/10.1890/1051-0761(1998)008[0128:HHDTFD]2.0.CO;2
Livingston, R. J. 1991. Historical relationships between research and resource management in the Apalachicola River estuary. Ecological Applications 1:361-382. http://dx.doi.org/10.2307/1941897

Livingston, R. J. 2002. Trophic organization in coastal systems. CRC Press, Boca Raton, Florida, USA. http://dx.doi. org/10.1201/9781420040852

Livingston, R. J. 2015. Climate change and coastal ecosystems: long-term effects of climate and nutrient loading on trophic organization. CRC Press, Boca Raton, Florida, USA.

Livingston, R. J., X. Niu, F. G. Lewis III, and G. C. Woodsum. 1997. Freshwater input to a Gulf estuary: long-term control of trophic organization. Ecological Applications 7:277-299. http:// dx.doi.org/10.1890/1051-0761(1997)007[0277:FITAGE]2.0.CO;2

Ludwig, D., B. Walker, and C. S. Holling. 1997. Sustainability, stability, and resilience. Conservation Ecology 1(1): 7. [online] URL: http://www.consecol.org/vol1/iss1/art7

Margerum, R. D. 2008. A typology of collaborative efforts in environmental management. Environmental Management 41:487-500. http://dx.doi.org/10.1007/s00267-008-9067-9

McCormick, S. 2012. After the cap: risk assessment, citizen science and disaster recovery. Ecology and Society 17(4): 31. http:// dx.doi.org/10.5751/es-05263-170431

McCrea-Strub, A., K. Kleisner, U. R. Sumaila, W. Swartz, R. Watson, D. Zeller, and D. Pauly. 2011. Potential impact of the Deepwater Horizon oil spill on commercial fisheries in the Gulf of Mexico. Fisheries 36:332-336. http://dx.doi.org/10.1080/0363$\underline{2415.2011 .589334}$

Meehl, G. A., T. F. Stocker, W. D. Collins, P. Friedlingstein, T. Gaye, J. M. Gregory, A. Kitoh, R. Knutti, J. M. Murphy, A. Noda, S. C. B. Raper, I. G. Watterson, A. J. Weaver, and Z. C. Zhao. 2007. Global climate projections. Pages 749-848 in S. Solomon, D. Qin, M. Manning, Z. Chen, M. Marquis, K. B. Averyt, M. Tignor, and H. L. Miller, editors. Climate change 2007: the physical science basis. Contribution of Working Group I to the Fourth Assessment Report of the Intergovernmental Panel on Climate Change. Cambridge University Press, Cambridge, UK.

Menzel, R. W., N. C. Hulings, and R. R. Hathaway. 1966. Oyster abundance in Apalachicola Bay, Florida in relation to biotic associations influenced by salinity and other factors. Gulf Research Reports 2:73-96.

Mikalsen, K. H., and S. Jentoft. 2001. From user-groups to stakeholders? The public interest in fisheries management. Marine Policy 25(4):281-292. http://dx.doi.org/10.1016/s0308-597x (01)00015-X

Milly, P. C. D., J. Betancourt, M. Falkenmark, R. M. Hirsch, Z. W. Kundzewicz, D. P. Lettenmaier, and R. J. Stouffer. 2008. Climate change: stationarity is dead: whither water management? Science 319(5863):573-574. http://dx.doi.org/10.1126/science.1151915

National Research Council of the National Academies. 2006. Facing hazards and disasters: understanding human dimensions. The National Academies Press, Washington, D.C., USA.

Oczkowski, A. J., F. G. Lewis, S. W. Nixon, H. L. Edmiston, R. S. Robinson, and J. P. Chanton. 2011. Fresh water inflow and 
oyster productivity in Apalachicola Bay, FL (USA). Estuaries and Coasts 34:993-1005. http://dx.doi.org/10.1007/s12237-011-9383-9

Olsson, P., C. Folke, and F. Berkes. 2004. Adaptive comanagement for building resilience in social-ecological systems. Environmental Management 34:75-90. http://dx.doi.org/10.1007/s00267-003-0101-7

Ostrom, E. 1990. Governing the commons: the evolution of institutions for collective action. Cambridge University Press, Cambridge, UK. http://dx.doi.org/10.1017/cbo9780511807763

Ostrom, E. 2009. A general framework for analyzing sustainability of social ecological systems. Science 325:419-422. http://dx.doi.org/10.1126/science.1172133

Ozawa, C. P. 1991. Recasting science: consensual procedures in public policy making. Westview, Boulder, Colorado, USA.

Petes, L. E., A. J. Brown, and C. R. Knight. 2012. Impacts of upstream drought and water withdrawals on the health and survival of downstream estuarine oyster populations. Ecology and Evolution 2:1712-1724. http://dx.doi.org/10.1002/ece3.291

Pine, W. E., III, S. J. D. Martell, C. J. Walters, and J. F. Kitchell. 2009. Counterintuitive responses of fish populations to management actions: some common causes and implications for predictions based on ecosystem modeling. Fisheries 34:165-180. http://dx.doi.org/10.1577/1548-8446-34.4.165

Pine, W. E., III, C. J. Walters, E. V. Camp, R. Bouchillon, R. Ahrens, L. Sturmer, and M. Berrigan. 2015. The curious case of eastern oyster Crassostrea virginica stock status in Apalachicola Bay, Florida. Ecology and Society 20(3):46. http://dx.doi. org/10.5751/ES-07827-200346

Portes, A. 1998. Social capital: its origins and applications in modern sociology. Annual Review of Sociology 24:1-24. http://dx. doi.org/10.1146/annurev.soc.24.1.1

Prince, J., C. Walters, R. Ruiz-Avila, and P. Sluczanowski. 1998. Territorial user's rights and the Australian abalone (Haliotis sp.) fishery. Pages 367-376 in G. S. Jamieson, and A. Campbell, editors. Proceedings of the North Pacific symposium on invertebrate stock assessment and management. Canadian Special Publication of Fisheries and Aquatic Sciences 125. National Research Council of Canada, Ottawa, Ontario, Canada.

Rindone, P. R., and D. B. Eggleston. 2011. Predator-prey dynamics between recently established stone crabs (Menippe spp.) and oyster prey (Crassostrea virginica). Journal of Experimental Marine Biology and Ecology 407:216-225. http://dx.doi. org/10.1016/i.jembe.2011.06.018

Schulte, D. M., R. P. Burke, and R. N. Lipcius. 2009. Unprecedented restoration of a native oyster metapopulation. Science 325:1124-1128. http://dx.doi.org/10.1126/science.1176516

Sumaila, U. R., A. M. Cisneros-Montemayor, A. Dyck, L. Huang, W. Cheung, J. Jacquet, K. Kleisner. V. Lam, A. McCrea-Strub, W. Swartz, R. Watson, D. Zeller, and D. Pauly. 2012. Impact of the Deepwater Horizon well blowout on the economics of US Gulf fisheries. Canadian Journal of Fisheries and Aquatic Sciences 69:499-510. http://dx.doi.org/10.1139/f2011-171

Swift, F. 1898. The oyster-grounds of the west Florida coast: their extent, conditions, and peculiarities. Pages 185-187 in Proceedings and papers of the national fishery congress. Tampa, Florida, January 19-24. U.S. Commission of Fish and Fisheries. Washington, D.C., USA.

Tierney, K. J., M. K. Lindell, and R. W. Perry. 2001. Facing the unexpected: disaster preparedness and response in the United States. Joseph Henry Press, Washington, D.C., USA.

Twichell, D. C., B. D. Andrews, H. L. Edmiston, and W. R. Stevenson. 2006. Geophysical mapping of oyster habitats in a shallow estuary: Apalachicola Bay, Florida. Open-File Report 2006-1381. U.S. Geological Survey, Woods Hole, Massachusetts, USA.

United States Army Corps of Engineers (USACE). 1998. Water allocation for the Apalachicola-Chattahoochee-Flint (ACF) River Basin, main report of the draft environmental impact statement. Federal Register 63:53023-53024.

United States Department of Commerce (USDC). 2013. Letter from the Secretary of Commerce to the Governor of Florida. USDC, Washington, D.C., USA. [online] URL: http://www.nmfs. noaa.gov/sfa/sf3/disasters/FL Oysters 2011/Decision.pdf

Visser, J. M., C. E. Sasser, R. H. Chabreck, and R. G. Linscombe. 2002. The impact of a severe drought on the vegetation of a subtropical estuary. Estuaries 25:1184-1195. http://dx.doi. org/10.1007/BF02692215

Walters, C. J. 1986. Adaptive management of renewable resources. McMillan, New York, New York, USA.

Walters, C. J. 2007. Is adaptive management helping to solve fisheries problems? Ambio 36:304-307. http://dx.doi.org/10.1579/0044-7447 (2007)36[304:IAMHTS]2.0.CO;2

Wetz, M. S., and D. W. Yoskowitz. 2013. An 'extreme' future for estuaries? Effects of extreme climatic events on estuarine water quality and ecology. Marine Pollution Bulletin 69:7-18. http://dx. doi.org/10.1016/j.marpolbul.2013.01.020

Wilber, D. H. 1992. Associations between freshwater inflows and oyster productivity in Apalachicola Bay, Florida. Estuaries, Coastal and Shelf Science 35:179-190. http://dx.doi.org/10.1016/ $\underline{\mathrm{s} 0272-7714(05) 80112-\mathrm{X}}$

Wilberg, M. J., M. E. Livings, J. S. Barkman, B. T. Morris, and J. M. Robinson. 2011. Overfishing, disease, habitat loss, and potential extirpation of oysters in upper Chesapeake Bay. Marine Ecology Progress Series 436:131-144. http://dx.doi.org/10.3354/ meps09161

Yoskowitz, D., C. Santos, B. Allee, C. Carollo, J. Henderson, S. Jordan, and J. Ritchie. 2010. Proceedings of the Gulf of Mexico ecosystem services workshop. Harte Research Institute for Gulf of Mexico Studies, Corpus Christi, Texas, USA. 